\title{
Types and Meanings of Compound Words Found in Medical Textbook Entitled Gray's Basic Anatomy
}

\author{
Ni Kadek Mita Yanti \\ English Department, Faculty of Arts, Udayana University \\ [mitapocron@gmail.com] \\ *Corresponding Author
}

\begin{abstract}
The title of this study is "Types and Meanings of Compound Words Found in Medical Textbook Entitled Gray's Basic Anatomy". This study aims to identify the types and analyze the meanings of compound words found in a medical textbook entitled "Gray's Basic Anatomy". The data of this study were collected by using documentation method with note taking technique. This descriptive qualitative study used two theories to analyze the data. The types of compound words were identified by using the theory of compounding proposed by Plag (2003). Meanwhile, the types of meaning of the compound words were analyzed based on the theory of meaning proposed by Ulmmann (1972). After analyzing the data, three types of compound words were found in the medical textbook entitled "Gray's Basic Anatomy", they are nominal, adjectival, and neoclassical compounds. Nominal compounds found totaled 37 while adjectival compounds found totaled 42 and neoclassical compound found totaled 135 out of 214. However, verbal compounds were not found in this medical textbook. Based on the analysis of meaning, two types of meaning were found in this medical textbook, they are transparent and opaque meaning. The compounds which have transparent meaning totaled 197 while the compounds which have opaque meaning only totaled 17.
\end{abstract}

Keywords: nominal, adjectival opaque, neoclassical, transparent

\begin{abstract}
Abstrak
Penelitian ini berjudul "Types and Meanings of Compound Words Found in Medical Textbook Entitled Gray's Basic Anatomy”. Tujuan dari penelitian ini yakni untuk mengidentifikasi tipetipe dan makna-makna dari "compound word" yang ditemukan di dalam buku kedokteran berjudul "Gray's Basic Anatomy". Data dari penelitian ini dikumpulkan menggunakan metode dokumentasi dengan teknik pencatatan. Penelitian ini adalah penelitian kualitatif deskriptif yang menggunakan dua teori untuk menganalisis data. Tipe-tipe "compound word" diidentifikasi dengan menggunakan teori "compounding” yang diusulkan oleh Plag (2003) sementara jenis makna yang terkandung di dalam suatu "compound word" dianalisis menggunakan teori makna yang diusulkan oleh Ulmmann (1972). Setelah menganalisis data, ada tiga jenis "compound word" yang ditemukan di buku kedokteran yang berjudul "Gray's Basic Anatomy". Tiga jenis tersebut meliputi "nominal", "adjectival", dan "neoclassical" compounds. Jumlah "nominal compound" yang ditemukan di sumber data sebanyak 37, sementara "adjectival compound" ditemukan sebanyak 42 dan "neoclassical compound" ditemukan sebanyak 135 dari jumlah keseluruhan 214. Di sisi lain, "verbal compounds" tidak ditemukan di buku kedokteran tersebut. Berdasarkan analisa makna, ada dua jenis makna yang ditemukan di buku kedokteran yang berjuadul "Gray's Basic Anatomy". Kedua makna tersebut meliputi makna "transparent" dan makna "opaque". "Compound words" yang memiliki makna transparent ditemukan sebanyak 197 sedangkan "compound words" yang memiliki makna opaque hanya ditemukan sebanyak 17.
\end{abstract}

Kata kunci: nominal, adjectival opaque, neoclassical, transparent 


\section{Background of the Study}

Morphology is a study that focuses on how words are formed or constructed. In morphology, there is a process which is called morphological process that plays the most important role to create a new word. The morphological process itself can be divided into three main processes; those are compounding, affixation, and conversion (Katamba, 1993:112). Among those processes, this study only focuses on words that are created through the compounding process. Compounding is defined as the process of combining two or more words into a single entity that expresses a single idea. The product of this process is called compound word. It is a new word formed by the combination of two or more words.

This study focuses on the analysis of types and meanings of compound words found in a medical textbook entitled "Gray's Basic anatomy". It contains a detailed description of human physical structure and additional clinical and imaging materials. This textbook is used to help student enhance their knowledge about anatomy as it is a basic science in medical education. In this medical textbook, the compound words which are related to the medical term can be found. Those specific compounds are different from the compound words which are usually found in novels, newspapers, or other books. Therefore, it is interesting to analyze compound words found in this medical textbook.

\section{Problems of the Study}

a) What types of compound words are found in the medical textbook entitled "Gray's Basic Anatomy"?

b) What meanings of compound words are found in the medical textbook entitled "Gray's Basic Anatomy"?

\section{Aims of the Study}

a) To identify types of compound words found in the medical textbook entitled "Gray's Basic Anatomy".

b) To analyze the meanings of compound words found in the medical textbook entitled "Gray's Basic Anatomy".

\section{Research method}

Research method is the way or procedure required in conducting a research to produce a specific study. The research method in this study involves four main aspects, namely data source, method and technique of collecting data, method and technique of analyzing data, and method and technique of analyzing data.

\subsection{Data source}

The study used compound words which were obtained from a medical textbook entitled "Gray's Basic Anatomy". This textbook is concerned with the physical structure (anatomy) of human as the basic science of medicine. It has 610 pages which are divided into 8 chapters that contain explanations of regional anatomy, surface anatomy, and clinical material. This textbook was chosen as the data source since it contains compound words which were needed for this research.

\subsection{Method and Technique of Collecting data}

In this study, documentation method was used to collect the data of compound words from the medical textbook entitled "Gray's Basic Anatomy". The technique used in collecting data was note taking, which took several steps as follows: first, reading the medical textbook entitled "Gray's Basic Anatomy" carefully. After that, the compound words which were found in this medical textbook were noted. 


\subsection{Method and Techniques of Analyzing data}

This study used a descriptive qualitative method to analyze the types and meanings of compound words. In this study, the data were analyzed by using several techniques as follows: first, the types of compound words were identified based on the theory of compounding proposed by Plag (2003). After identifying the types, the meanings of compound words were analyzed based on the theory proposed by Ullmann (1972). In addition, the meanings of specific compounds related to the medical term were defined by using Merriam-Webster Medical Dictionary. Online (2018).

\subsection{Method and Technique of \\ Presenting the Result of Data Analysis}

This study used the formal and informal method to present the analysis. The formal method can be defined as a way of presenting analysis in which tables, diagrams, or symbols are used. Meanwhile, the informal method means the analysis is presented in the form of words, sentence, or paragraphs. The techniques of presenting the analysis in this study involve several steps: first, several data were chosen to represent the types of compound words. After that, each collected data was presented in the form of a diagram to show its components. Then, the explanation of the type and meaning of each compound word was given below the diagram in the form of a paragraph.

\section{Results and discussions}

\subsection{Types and Meanings of Compound words}

According to Plag (2003), there are four types of compounds; they are nominal, adjectival, verbal, and neoclassical compounds. However, there are only three types of compounds found in the study; namely nominal, adjectival, and neoclassical compounds.

\subsubsection{Nominal Compounds}

A nominal compound can be defined as a compound that has a noun as its head. A nominal compound can have noun, verb, adjective, or preposition as its non-head. The example of nominal compounds is given as follows:

1. Trigger Finger

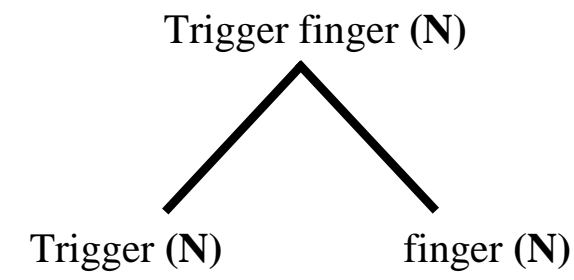

Based on the diagram above, the compound word 'trigger finger' is formed by combining two words, namely 'trigger' and 'finger'. Based on the lexical category of a word, both of these words are nouns. The combination of the words 'trigger' and 'finger' creates the compound word 'trigger finger' that belongs to a nominal compound. It is considered as a nominal compound since it is formed by nouns and the referent of the compound as a whole is also a noun.

Semantically, the noun trigger can be defined as something that capable to cause something else to happen. It also can be defined as a lever of a gun that causes the gun to fire. Meanwhile, the noun finger can be defined as a part of the hand, especially any of five members at the terminal part of a hand. These two words are combined to form the nominal compound 'trigger finger' that brings a new meaning. This new meaning cannot simply be predicted just by looking at the meaning of the word trigger and finger. In the data source, the compound word 'trigger finger' does not mean "the finger that used to pull a trigger of a gun' or 'the finger that is related to a trigger". However, the meaning of 'trigger finger' is an abnormal condition in which flexion 
or extension of a finger may be momentarily obstructed by spasm followed by a snapping into place [Def.1]. (n.d.). In Merriam-Webster Medical Dictionary Online, retrieved February 21, 2018, from https://www.merriamwebster.com/medic al/trigger\%20finger. Another definition of 'trigger finger' stated in the medical textbook entitled 'Gray's Basic Anatomy' (2012:401) is a common disorder of late childhood and adulthood and is typically characterized by catching or snapping and occasionally locking of the flexor tendons in the hand. Based on those definitions, it can be concluded that this compound word has opaque meaning; it has a meaning that cannot be determined easily from the meanings of its elements. Trigger finger does not simply refer to a finger that pulls a trigger. This compound word, nevertheless, refers to a kind of disorder.

\subsubsection{Adjectival Compound}

The adjectival compound is a type of compound word in which two words are combined into an adjective or it is a compound which has adjective as its head. An adjectival compound can have a noun or another adjective as its non-head. The example of adjectival compound is presented as follows:

\section{Proton-rich}

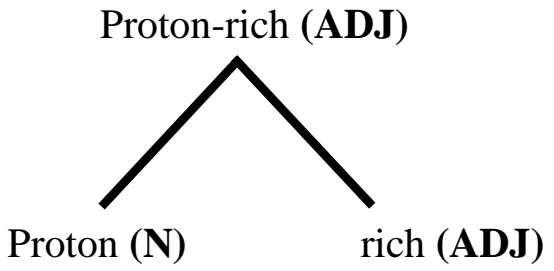

Morphologically, the compound word 'proton-rich' is formed by combining two words, namely the word 'proton' that belongs to a noun and the word 'rich' that belongs to an adjective. These two words are connected by a hyphen so that it creates a compound word 'proton-rich'. This compound belongs to adjectival compound since it has an adjective as its head and in the data source, it is used to describe the noun 'radionuclides', especially in the sentence positrons are emitted from the decay of proton-rich radionuclides (Drake, 2012:6).

The meaning of the compound word 'proton-rich' is predictable from the meaning of the word proton and rich. The word 'proton' can be defined as $a$ particle that has a positive electrical charge as part of the nucleus of an atom. Meanwhile, the word 'rich' can be defined as having or containing a large amount of something. The meaning of proton-rich (radionuclides) is the radionuclides that having or containing a large number of protons. This meaning can be determined from the meaning of 'proton' and 'rich'. Thus, it can be concluded that this compound word has a transparent meaning.

\subsubsection{Neoclassical Compound}

Neoclassical compound is a special type of compound words since it is not formed by combining two or more words as the other types of compound. It is formed by combining forms which are derived from the Greek or Latin origin. A combining form cannot stand alone in a sentence and it must be combined with a word or another combining form to create a new word. The example of neoclassical compound is given as follows:

\section{Pathology}

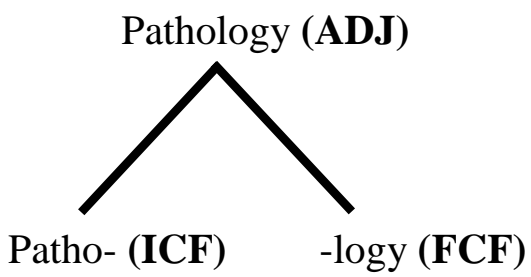

The compound word 'pathology' is formed by two combining forms, namely the initial and final combing form. The initial combining form in this compound 
is 'phato-' and the final combining form is '-logy'. 'Patho-' is considered as an initial combining form since it occupies the initial position of the compound. Meanwhile, '-logy' is called a final combining form since it occupies final position of the compound. Both of these elements are considered as combining forms since they cannot stand independently in a sentence as free words. The ICF 'patho-' is combined with the FCF 'logy-' to form the neoclassical compound 'pathology'.

Based on the analysis of meaning, the neoclassical compound 'pathology' is considered to have a transparent meaning. A compound is considered to have this meaning when its meaning is able to be predicted from the meanings of its elements. The meaning of 'pathology' can be predicted from the meaning of the initial combining form 'patho-' and the final combining form '-logy'. Based on Merriam-Webster Medical Dictionary Online (2018), the ICF 'patho-' is derived from Greek word phatos with meaning disease or pathological state, whereas the FCF 'logy' is derived from Greek logos or Latin logia that indicates the science, study, theory, or area of knowledge. Based on these meanings, it can be concluded that the meaning of 'pathology' is the study of disease or the area of knowledge that concerns on diseases. The more complex definition of 'pathology' stated in Merriam-Webster Medical Dictionary Online (2018) is the science or study of the essential nature of diseases and especially of the structural and functional changes produced by them.

\section{Conclusion}

Based on the data analysis that has been done, it can be concluded that there are three types of compound words found in the medical textbook entitled "Gray's Basic Anatomy". Those types are nominal, adjectival, and neoclassical compound words. The neoclassical compound is the most common type found in the data source since there are 135 compounds belong to this type out of 214 compounds words. The second common type of the compound word found is the adjectival compound as there are 42 compounds belong to this type. Meanwhile, the least type of compound word found is the nominal compound with only 37 compound words.

Based on the analysis of meanings of the compound words, there are two types of meaning found in this medical textbook, namely transparent and opaque meaning. Transparent meaning occurred more frequently than opaque meaning as there are 197 compounds found having this meaning. Meanwhile, the compound words which have opaque meaning are only found 17 in the data source.

\section{References}

Katamba, Francis. 1993. Morphology. London: Macmillan Press LTD.

Merriam-Webster Medical Dictionary. 2018. Available on https://www.merriam-webster online/medical February 18, 2017

Plag, Ingo. 2003. Word-formation in English. Cambridge textbooks in linguistics. New York: Cambridge University Press

Ullmann, Stephen. 1972. Semantics an Introduction to the Science of Meaning. Great Britain: Butler and Tanner Ltd 